Xây dựng khẩu phần ăn cân đối, hợp lý theo từng độ tuổi, cần chú trọng những học sinh suy dinh dưỡng và thừa cân béo phì.

\section{TÀI LIỆ THAM KHẢO}

1. Analytix BI's (2012), South Africa Country Report: Fast Food Consumers Trends 2007- 2011.

2. Viện dinh dưỡng - Bộ Y tế (2016), Nhu cầu dinh dưỡng khuyển nghị cho người Việt Nam, Nhà xuất bản $Y$ hoc.

3. Đố Ngọc Diệp và Nguyễn Trí Dững (2011), "Thừa cân, béo phì và môtt số đăc điểm dich tễ hoc ở hoc sinh tiểu hoc tai quân 10 TPHCM năm 20092010", Thời sự Y học số 67̀, tr. 3-6.

4. Trương Thị Thùy Dương, Nguyễn Thị Thanh
Tâm, Trân Thị Hồng Vân, Trân Thị Huyên Trang (2020), Khẩu phần của học sinh dân tộc thiểu số tai hai trường phổ thông dân tôc nôi trú tỉnh Cao Bằng năm 2019, ISSN 1859-2872, Số chuyên đề, Tạp chí Y Dược lấm sàng 108, tr.132-138.

5. Đào Thị Ngọc Trâm, Đố Thị Hoài Thương, Đố Thị Ngoc Diệ̂p (2018), "Khẩu phân ăn của học sinh trướng THCS Nguyên Chí Thanh tai thi xã Gia Nghĩa tỉnh Dak Nông", Tạp chí Y học Thành phố Hố Chí Minh. 22(1), tr. 253்-259.

6. Nguyễn Văn Toán, Đoàn Thị Thu Huyên, Lê Thị Hương (2013), "Thực trang thừa cân béo phì và môt số yêu tố liên quan ở hoc sinh trung hoc cơ sở thành phố Bắc Giang năm 2011", Tạp chí Nghiên cứu Y học, số 1, tr. 112-118.

\title{
ĐAU DÂY V DO HộI CHỨNG XUNG ĐộT THẦN KINH MẠCH MÁU - NHẤN MộT TRƯờNG HỢP LÂM SÀNG
}

\section{TÓM TẮT}

Xung đột thần kinh mạch máu là nguyên nhân gây đau dây $\mathrm{V}$ (hay còn gọi là dây thân kinh sinh ba) phổ biến nhất ở người trưởng thành. Các phương tiện hình ảnh, đặc biệt là cộng hưởng từ (CHT), có vai trò quan trong trong chẩn đoán nguyên nhân cũng như giúp chẩn đoán phân biệt và hỗ trợ lên kế hoạch trước mổ. Việc điều trị đau dây $\mathrm{V}$ do hội chứng xung đột thần kinh mạch máu có hai phương pháp chính là điều trị nôi khoa hoăc phẫu thuât, trong đó nhiều nghiên cứu chứng minh hiệu quả của điều trị phẫu thuật. Chúng tôi xin trình bày một trường hợp lâm sàng về bênh nhân đau dây $V$ do hội chứng xung đột thần kinh mạch máu, được chẩn đoán xác định trên cộng hưởng từ và điều trị phẫu thuật giảm áp mang lại hiệu quả tốt.

Tư khoá: xung đột thần kinh mạch máu, đau dây V, cộng hưởng từ.

\section{SUMMARY}

TRIGEMINAL NEURALGIA CAUSING BY NEUROVASCULAR CONFLICT SYNDROME: A CASE REPORT

Neurovascular conflict syndrome is the most frequent cause of trigeminal neuralgia (TN) in adult. Imaging methods, particularly magnetic resonance imaging (MRI), play a crucial role in diagnosis as well as guilding preoperative plan. Treatment options in TN due to neurovascular conflict include medications and surgery, in which many studies demonstrated the effectiveness of surgical treatment. We introduced a case of trigeminal neuralgia causing by neurovascular

*Hệ thống Y tế Vinmec, Hà Nội, Việt Nam

Chịu trách nhiệm chính: Vũ Huy Hoàng

Email: v.hoangvh1@vinmec.com

Ngày nhận bài: 18.5.2021

Ngày phản biện khoa học: 2.7.2021

Ngày duyệt bài: 19.7.2021 conflict which was diagnosed by MRI and the patient had good recovery from microvascular decompression surgery.

Keywords: neurovascular conflict syndrome, trigeminal neuralgia, magnetic resonance imaging, MRI

\section{TỔNG QUAN}

Xung đột thần kinh mạch máu là hội chứng mà trong đó có sự tác động cơ học trực tiếp vào dây thần kinh bởi mạch máu. Dây thần kinh $\mathrm{V}$ là dây thân kinh thường gặp hội chứng này nhất, với tỷ lệ khoảng 4-20 ca/100000 người; ngoài ra xung đột có thể gặp ở một số dây khác như dây VII-VIII, dây IX, dây X[1],[4]. Không phải trường hợp nào có xung đột thần kinh mạch máu trên hình ảnh cũng có biểu hiện lâm sàng rõ ràng, một số nghiên cứu chỉ ra rằng các trường hợp có triệu chứng lâm sàng thường liên quan đến động mạch và vị trí tiếp xúc là vùng chuyển tiếp của dây thần kinh [1]. Việc sử dụng chẩn đoán hình ảnh, đặc biệt là chụp cộng hưởng từ, được chứng minh có giá trị cao trong chẩn đoán trước mổ hội chứng xung đột thần kinh mạch máu [2].

\section{CASE LÂM SÀNG}

Bệnh nhân nam, 63 tuổi, tiền sử khoẻ mạnh. Bệnh nhân xuất hiện các cơn đau nửa mặt bên trái từ khoảng 5 năm nay, lúc đầu chỉ biểu hiện nhẹ và xuất hiện chủ yếu khi có kích thích. Về sau các cơn đau xuất hiện tự phát và ngày càng nhiều khiến bệnh nhân thay đổi thói quen sinh hoạt và mất ngủ. Bệnh nhân đã đi khám trước đây và điều trị nội khoa theo hướng đau dây thần kinh $V$ nhưng không cải thiện đáng kể. Tại thời điểm vào bệnh viện của chúng tôi, các cợn đau của bệnh nhân xuất hiện gần như liên tục, 
mức độ 7 theo thang điểm đau Numeric Rating Scales (NRS) [5], ở nửa mặt bên trái theo vùng chi phối thần kinh $V$, không có biểu hiện yếu hay liệt mặt đi kèm. Chúng tôi hướng tới một trường hợp đau dây thần kinh $V$ bên trái và chụp $\mathrm{CHT}$ sọ nã̃o trong đó có chuỗi xung đánh giá các dây thần kinh Sọ CISS 3D và chuỗi xung động mạch TOF 3D. Trên hình ảnh $\mathrm{CHT}$ có tiếp xúc giữa động mạch tiểu não trước trên bên trái với dây $V$ ngay sát gốc xuất phát kèm lệch nhẹ dây $V$ (Hình 1). Kích thước dây $V$ hai bên còn khá tương đồng.

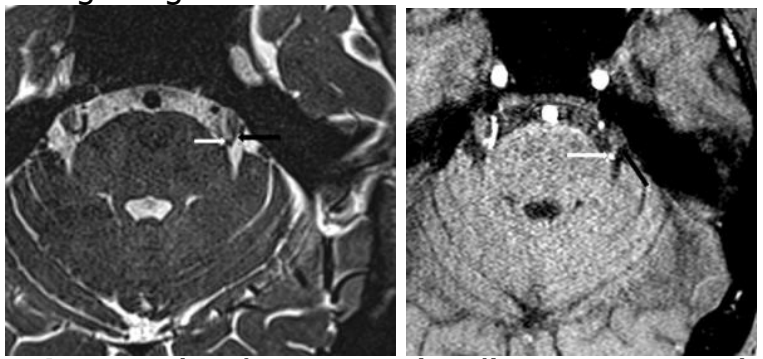

Hinh 1: Hình ảnh xung đột thần kinh mạch máu giữa động mạch tiểu não trước trên bên trái (mũi tên trăng) và dây $V$ (mũi tên đen) trên 2 chuối xung CISS 3D (bên phải) và TOF 3D (bên trái).

Bệnh nhân được chẩn đoán đau dây $\mathrm{V}$ do xung đột thần kinh mạch máu và chỉ định điều trị để giải ép bằng cách đặt một tấm ngăn bằng Teflon. Quá trình phẫu thuật diễn biến thuận lợi. Bệnh nhân được tái khám sau một tháng, triệu chứng đau nửa mặt trái trên lâm sàng đã cải thiện rõ rệt, mức độ đau chỉ ở mức 1 điểm. Trên cộng hưởng từ không còn hình ảnh tiếp xúc giữa động mạch tiểu não trước trên và dây $\mathrm{V}$ bên trái (Hình 2).

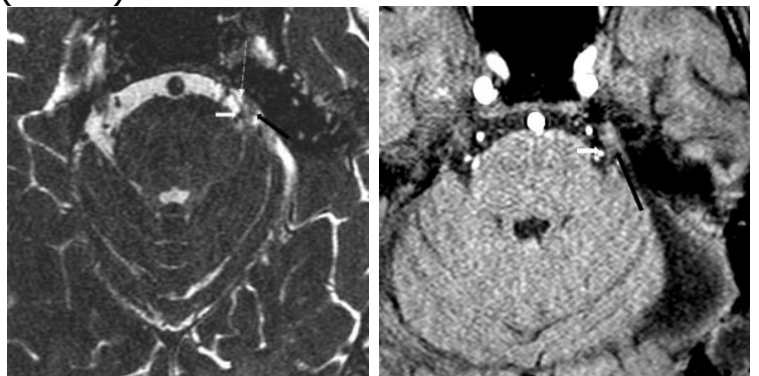

Hình 2: Hình ảnh sau mô, có hình tấm ngăn

Teflon (mũi tên trăng nét rời) ngăn cách động mạch tiểu não trước trên (mũi tên trănng nét liền) và dây $V$ (mũi tên đen).

\section{BÀN LUẬN}

Hội chứng xung đột thần kinh mạch máu là nguyên nhân gây đau thần kinh $V$ nhiều nhất ở người trưởng thành, với tỷ lệ gặp khoảng 4-20 ca/100000 người, bên cạnh các nguyên nhân khác như u, viêm dây thần kinh, chấn thương hoăc nhiễm trùng, dị dạng mạch [1],[6]. Hội chứng này thường gặp ở nữ nhiều hơn nam, chủ yếu người trên 60 tuổi và một số ít trường hợp ghi nhận ở trẻ em [4], [6]. Các triệu chứng lâm sàng thường gặp trên một bệnh cảnh điển hình là các cơn đau nhói nửa mặt tương ứng chi phối của thần kinh V (nhánh V1 và V2), xuất hiện khi có các kích thích nhẹ như đánh răng hoặc khi trang điểm. Giữa các cơn đau đa số bệnh nhân cảm thấy bình thường, tuy nhiên khi tình trạng này kéo dài các cơn đâu sẽ tăng dần cả về cường độ và tần suất xuất hiện [1]. Không phải trường hợp nào có dấu hiệu về mặt hình ảnh cũng có biểu hiện lâm sàng, các trường hợp có biểu hiện rõ thường là xung đột của thần kinh và động mạch hơn là tĩnh mạch, điều này có thể giải thích do áp lực của động mạch lớn hơn [1]. Ngoài ra vị trí dây thần kinh tiếp xúc cũng có vai trò lớn, trong đó nhiều tác giả ủng hộ vị trí này có liên quan đến vùng trần (hay root entry zone) của dây thần kinh [1]. Đối với dây $\mathrm{V}$ một số tác giả thấy rằng vị trí tiếp xúc cách vị trí đi ra khỏi nhu mô não dưới $3 \mathrm{~mm}$ chiếm phần lớn các trường hợp có triệu chứng [1].

Trong các phương tiện chẩn đoán hình ảnh, cộng hưởng từ được nhiều tác giả cho là phương tiện có giá trị cao trong chẩn đoán [2]. Nhiều tác giả khuyến khích việc sử dụng các chuỗi xung T2W độ phân giải cao (hay CISS 3D- với các lát cắt mỏng dưới $1 \mathrm{~mm}$ ) kết hợp với chuỗi xung đánh giá mạch máu (TOF 3D hoặc tiêm thuốc đối quang từ') cho phép đánh giá tổn thương tốt hơn [1],[2],[3].

Điêu trị đau dây $V$ do xung đột thần kinh mạch máu bước đầu là điều trị nội khoa bằng các thuốc giảm đau như carbamazepine [3],[4]. Nếu không thuyên giảm sẽ mổ để giải áp cho thần kinh. Theo một số tác giả, việc mổ giải áp mang lại hiệu điều trị tốt, khả năng giảm đau lên tới hơn 90\% [1],[3],[4].

Về bệnh nhân của chúng tôi có biểu hiện lâm sàng chủ yếu là đau, rối loạn cảm giác theo phân bố của thần kinh $V$ bên trái, đồng thời về mặt hình ảnh trên cộng hưởng từ có biểu hiện của việc xung đột giữa động mạch tiểu não trước trển và thần kinh $V$ bển trái tại vị ngay sát chỗ xuất phát, vì những lý do trên mà chúng tôi đưa ra chẩn đoán đau dây $\mathrm{V}$ do xung đột thần kinh mạch máu. Vì bệnh nhân này đã điều trị nội khoa đáp ứng kém trước đó nên chúng tôi đã chỉ đinh phấu thuật. Bệnh nhân sau đó được phẫu thuật nhằm giảm áp lực của mạch máu lên dây thần kinh bằng cách đặt một tấm ngăn giữa 
động mạch tiểu não trước trên và thần kinh V bền trái. Sau phẫu thuật diễn biến thuận lợi, các biểu hiện lâm sàng được cải thiện rõ rệt, đồng thời về mặt hình ảnh cũng không còn biểu hiện xung đột thần kinh mạch máu trên phim cộng hưởng từ.

\section{KẾT LUẬN}

Xung đột thần kinh mạch máu là nguyên nhân gây đau dây $V$ nhiều nhất ở người trưởng thành. Mặc dù các biểu hiện lâm sàng có vai trò quan trọng trong chẩn đoán, chúng tôi cũng khuyến khích việc sử dụng các phương tiện chẩn đoán hình ảnh, đặc biệt là cộng hưởng từ có giá trị cao trong chẩn đoán và chẩn đoán phân biệt, bền cạnh đó còn góp phần lên kế hoach cho phẫu thuật. Mặt khác việc cân nhắc phấu thuật giải áp cũng là một phướng án hiệu quả để giảm đau cho bệnh nhẩn khi các phương pháp điều trị nội khoa không mang lại kết quả tốt.

TÀI LIỆ THAM KHẢO
1. Haller S., Etienne L., Kövari E. và cộng sự. (2016). Imaging of Neurovascular Compression Syndromes: Trigeminal Neuralgia, Hemifacial Spasm, Vestibular Paroxysmia, and Glossopharyngeal Neuralgia. AJNR Am J Neuroradiol, 37(8), 1384-1392.

2. Leal P.R.L., Froment J.-C., và Sindou M. (2010). MRI sequences for detection of neurovascular conflicts in patients with trigeminal neuralgia and predictive value for characterization of the conflict. Neurochirurgie, 56(1), 43-49.

3. Hughes M.A., Frederickson A.M., Branstetter B.F. và cộng sự. (2016). MRI of the Trigeminal Nerve in Patients With Trigeminal Neuralgia Secondary to Vascular Compression. AJR Am J Roentgenol, 206(3), 595-600.

4. Baldauf J., Rosenstengel $C_{\text {., }}$ và Schroeder H.W.S. (2019). Nerve Compression Syndromes in the Posterior Cranial Fossa. Dtsch Arztebl Int, 116(4), 54-60.

5. Fink R. (2000). Pain assessment: the cornerstone to optimal pain management. Proc (Bayl Univ Med Cent), 13(3), 236-239.

6. Childs A.M., Meaney J.F., Ferrie C.D. và cộng sư. (2000). Neurovascular compression of the trigeminal and glossopharyngeal nerve: three case reports. Arch Dis Child, 82(4), 311-315.

\section{XÁC ĐỊNH THIẾT BI VÀ PHƯƠNG PHÁP PHÂN TÍCH CHUẨN CHO SÁU THÔNG SỐ HÓA SINH AST, ALT, CHOLESTEROL, TRIGLYCERIDE, GLUCOSE VÀ PROTEIN}

\section{Trần Hữu Tâm*, Trương Quân Thụy*, Võ Ngọc Nguyên*, Vũ Đình Dũng*, Nguyễn Thị Hồng Phương*, Nguyễn Đức Quỳnh Nhu**, Vũ Thị Như Oanh*, Lê Thị Thùy Nhu*, Nguyễn Ngọc Cường*. \\ AMS Diagnostics, Agappe, Spinreact. \\ Tư khóa: thiết bị chuẩn, vật liệu tham chiếu, phương pháp chuẩn, phương pháp tham chiếu. \\ SUMMARY \\ IDENTIFY STANDARD ANALYTICAL \\ EQUIPMENTS AND METHODS FOR SIX \\ CHEMICAL PARAMETERS AST, ALT, CHOLESTEROL, TRIGLYCERIDE, GLUCOSE AND PROTEIN}

\section{TÓM TẮT}

Các xét nghiệm AST, ALT đại diện cho các bệnh về gan, xét nghiệm Glucose đại diện cho các bệnh về tiểu đường, Protein toàn phần đại diện cho các bệnh về chức năng thân, xét nghiêm Cholesterol và Triglyceride đại diện cho các bệnh về rối loạn chuyển hóa lipid và xơ vữa đông mach $[1,2,3]$. Nghiên cứu nhằm xác định thiết bị và phương pháp phân tích chuẩn cho 6 thông số dựa trên phương pháp tham chiếu và vật liệu tham chiếu. Kết quả nghiên cứu xác định được phương pháp chuẩn cho xét nghiệm AST, ALT là Trisbuffer without pyridoxal-5-phosphate, Glucose là Glucose oxidase, Protein toàn phân là Biuret reaction, Cholesterol là Cholesterol oxidase, Triglyceride là Lipase/GPO-PAP no correction, các thiết bị được sử dụng là các thiết bị của Abbott, Beckman Coulter, Erba Mannheim, Roche, Chema diagnostic,

*Trung tâm Kiểm chuẩn Xét nghiệm TP.HCM

Chịu trách nhiệm chính: Trần Hữu Tâm

Email: trhuutam@yahoo.com

Ngày nhận bài: 14.5.2021

Ngày phản biện khoa học: 30.6.2021

Ngày duyệt bài: 12.7.2021
AST, ALT tests represent for liver diseases, Glucose test represents for diabetes, Total Protein represents for diseases of kidney function, Cholesterol and Triglycerides tests represent for diseases of duslipidemia and atherosclerosis $[1,2,3]$. The study aimed to identify standard analytical equipment and methods for 6 parameters based on reference methods and reference materials. The research results determined that the standard method for testing AST, ALT is Trisbuffer without pyridoxal-5-phosphate, Glucose is Glucose oxidase, Total protein is Biuret reaction, Cholesterol is Cholesterol oxidase, Triglyceride is Lipase/GPO-PAP no correction, the equipments were Abbott, Beckman Coulter, Erba 